www.jmscr.igmpublication.org

Index Copernicus Value: 79.54

ISSN (e)-2347-176x ISSN (p) 2455-0450

crossrefDOI: https://dx.doi.org/10.18535/jmscr/v7i3.160

\title{
Clinical and histopathological correlation of ovarian neoplasms: A retrospective study
}

\author{
Authors \\ Dr Sachin Sharma, Prof. Dr C.V. Kulkarni, Prof. Dr Ashok Yadav, \\ Dr Minakshi Rajput* \\ *Corresponding Author \\ Minakshi Rajput \\ Email: minakshirajput79@gmail.com
}

\section{Abstract}

Objectives: o study the clinical and histopathological correlation of ovarian neoplasms.

Material and method: This retrospective study of two year duration from 2016 to 2018 were conducted in pathology department of Mahatma Gandhi Medical College and Maharaja Yeshwantrao Hospital, a tertiary care hospital of, Indore (M.P).Total 140 cases with ovarian lesion were studied. Presenting clinical symptoms such as abdominal mass, abdominal pain, menstrual irregularities, weight loss and ascites and related information about age, parity, family history, bilaterality, provisional diagnosis and histopathological analysis were collected from records.

Result: In the present study 140 cases with ovarian lesion were studied out of which non neoplastic lesions were 90 (64.2\%) cases and neoplastic were 50 cases (i.e. 35.7\%). In neoplastic category majority belongs to benign neoplasm 26/50 (52.0\%) then malignant tumors $21 / 50$ (42.5\%). Surface epithelial tumours (80\%) were common histopathological findings with most of the patient present clinically with abdominal mass in their late reproductive age group(41-60 years).

Conclusion: Ovarian pathology is the widest and most complex problems in modern gynecology mainly through ovarian tumours. There is wide spectrum of clinical and pathological features of ovarian neoplasm. Proper clinical and histopathological correlation of and categorization according to WHO classification of ovarian neoplasm help in early diagnosis as well as prognosis of ovarian tumors. Histopathological examination remains the gold standard for diagnosing ovarian neoplasms.

Keywords: Ovarian neoplasm, histopathological types.

\section{Introduction}

Ovarian pathology is the widest and most complex problems in modern gynecology mainly through ovarian tumours. ${ }^{[1]}$ Primary neoplasms of ovary comprise benign and malignant lesions, which may present superficial germinative epithelial differentiation of the stromal sexual cord. It is the third most common site of primary malignancy in female genital tract after cervix and endometrium accounting for $30 \%$ of all cancers of female genital tract. ${ }^{[2]}$

Malignant ovarian tumors are responsible for approximately $6 \%$ of all cancers affecting women, and correspond to the seventh most frequent cause of death, for around $80 \%$ of the cases are diagnosed in advanced stages. ${ }^{[3,4]}$ Ovarian cancer 
has an unknown natural evolution, starting often insidiously, without specific symptoms; the diagnosis is put during a routine exam. It is associated with an overall mortality of $75 \%$, but can be cured in up to $90 \%$ of cases if diagnosed while still limited to the ovaries. Despite the new techniques in imaging and genetics, the diagnosis of ovarian tumours is primarily dependent upon histological examination.

\section{Materials and Methods}

This retrospective study of two year duration from 2016 to 2018 were conducted in pathology department of Mahatma Gandhi Medical College and Maharaja Yeshwantrao Hospital, a tertiary care hospital of, Indore (M.P).Total 140 ovarian cases were studied. Presenting clinical symptoms such as abdominal mass, abdominal pain, menstrual irregularities, weight loss and ascites and related information about age, parity, family history, bilaterality, provisional diagnosis and histopathological analysis were collected from records.

\section{Results}

In the present study 140 cases with ovarian lesion were studied during 2 years from 2016 to 2018 . Among the 140 cases, non neoplastic lesions are found in $90(64.2 \%)$ cases, and 50 cases (i.e. $35.7 \%$ ) are neoplastic lesions.

Table 1:

\begin{tabular}{|l|c|c|}
\hline NATURE OF LESION & NUMBER OF CASES & PERCENTAGE \\
\hline NON NEOPLASTIC & 90 & $64.2 \%$ \\
\hline NEOPLASTIC & 50 & $35.7 \%$ \\
\hline TOTAL & 140 & $100 \%$ \\
\hline
\end{tabular}

Among neoplastic lesion benign lesion were more common 26(52\%) then malignant 21(42\%).03 borderline tumors $(06 \%)$ were identified. These lesions constitute respectively $18.5 \%, 10.0 \%$ and $2.1 \%$ of total number of cases studied.

\section{TABLE 2}

\begin{tabular}{|l|c|c|c|}
\hline NATURE OF LESION & NUMBER OF CASES(50) & PERCENTAGE & $\begin{array}{c}\text { PERCENTAGE OF TOTAL } \\
\text { CASES (140) }\end{array}$ \\
\hline BENIGN & 26 & $52 \%$ & $18.5 \%$ \\
\hline BORDERLINE & 03 & $06 \%$ & $2.1 \%$ \\
\hline MALIGNANT & 21 & $42 \%$ & $10.0 \%$ \\
\hline TOTAL & 50 & $100 \%$ & $35.7 \%$ \\
\hline
\end{tabular}

Clinical Presentation of patient with Ovarian Neoplasm: The most common symptoms was mass per abdominal 22 cases $(44 \%)$ followed by pain abdomen 14 cases(28\%), Menstrual abnormalities 12 cases $(24 \%)$ and Backache 5 cases $(12.5 \%)$.

\section{Table 3}

\begin{tabular}{|l|c|c|}
\hline CLINICAL FEATURES & NUMBER OF CASES & PERCENTAGE \\
\hline Abdominal mass & 22 & $44.0 \%$ \\
\hline Abdominal Pain & 14 & $28.0 \%$ \\
\hline Menstrual abnormalities & 12 & $24.0 \%$ \\
\hline Backache & 05 & $12.5 \%$ \\
\hline Ascites & 02 & $4 \%$ \\
\hline Weight loss & 4 & $8.0 \%$ \\
\hline
\end{tabular}


Age Distribution of Neoplastic Lesion: Most common age group affected by neoplastic lesions is reproductive age group of 31 to 45 years of age $30(60.0 \%)$. Malignant tumours were more common in menopausal age group of 46 to 60 years of age 16 (32\%) while benign tumours $15(30 \%)$ were more common in reproductive age group of 31 to 45 years of age.

\section{Table 4}

\begin{tabular}{|l|c|c|c|c|c|}
\hline & \multicolumn{3}{|c|}{ NEOPLASTIC } & & \\
\hline AGE YEARS & BENIGN & BORDERLINE & MALIGNANT & TOTAL & PERCENTAGE \\
\hline $0-10$ & 00 & 00 & 00 & 00 & 00 \\
\hline $11-20$ & 02 & 00 & 00 & 02 & $4.0 \%$ \\
\hline $21-30$ & 07 & 01 & 00 & 08 & $16.0 \%$ \\
\hline $31-40$ & 10 & 00 & 04 & 14 & $28.0 \%$ \\
\hline $41-50$ & 05 & 02 & 09 & 16 & $32.0 \%$ \\
\hline $51-60$ & 02 & 00 & 07 & 09 & $18.0 \%$ \\
\hline $61-70$ & 00 & 00 & 01 & 01 & $2.0 \%$ \\
\hline Total $(\%)$ & $26(52 \%)$ & $03(6.0 \%)$ & $21(42.0 \%)$ & 50 & $100 \%$ \\
\hline
\end{tabular}

Laterality of Ovarian Neoplasm: In present study, majority of ovarian neoplasm were unilateral 42 (84\%) and $08(16 \%)$ were bilateral.

Table: 5

\begin{tabular}{|l|c|c|c|c|}
\hline LATERALITY & BENIGN & MALIGNANT & BORDERLINE & TOTAL(50 cases) \\
\hline U/L & $23(88.4 \%)$ & $17(80.9 \%)$ & $02(66.0 \%)$ & $42(84.0 \%)$ \\
\hline B/L & $03(11.5 \%)$ & $04(19.0 \%)$ & $01(33.3 \%)$ & $08(16.0 \%)$ \\
\hline
\end{tabular}

Histological Types of Ovarian Neoplasm: Out of 50 neoplastic lesions 37 are surface epithelial tumours $(74 \%)$, 08 cases of germ cell tumours
$(16 \%)$ and 02 cases of sex cord stromal tumour $(4.0 \%)$ and $03(06 \%)$ case in other category.

Table: 6

\begin{tabular}{|l|c|c|}
\hline HISTOLOGICAL TYPE & NUMBER OF CASES & PERCENTAGE \\
\hline Surface Epithelial Tumours & 37 & $74 \%$ \\
\hline Germ Cell Tumours & 08 & $16 \%$ \\
\hline Sex Cord Stromal Tumours & 02 & $04 \%$ \\
\hline Others & 03 & $06 \%$ \\
\hline
\end{tabular}

\section{Discussion}

There is wide spectrum in clinical, morphological and histopathological features of ovarian neoplasms. In the present study 140 cases of ovarian lesions were analyzed. Clinicopathological correlation of 50 neoplastic cases was done. The clinical parameter like age, presenting clinical symptoms, ascites and bilaterality of ovarian tumors were compared with the histological type of tumors. 
Table 7: Frequency of benign and malignant tumors of ovary

\begin{tabular}{|l|c|c|c|}
\hline STUDY & BENIGN(\%) & BORDERLINE(\%) & MALIGNANT(\%) \\
\hline Gupta et al. & 72.9 & 4.1 & 22.9 \\
\hline George D Malkasian et & 56.9 & 00 & 43 \\
\hline Jha and karki & 83.9 & - & 16.1 \\
\hline Swamy GC Et Al,2010 & 71.6 & 4.6 & 25 \\
\hline Kuldeep et al & 82.35 & 3.6 & 13.9 \\
\hline Shoail et al & 74.8 & 1.6 & 23.3 \\
\hline RakaHota et el & 86 & 00 & 14 \\
\hline Present study & 52 & 06 & 42 \\
\hline
\end{tabular}

Table 8: Comparison of clinical presentation in ovarian neoplasm

\begin{tabular}{|l|c|c|c|c|c|}
\hline SYMPTOMS & Yasmin et al & Kuldeep et al & $\begin{array}{c}\text { Lina Baru } \\
\text { et al }\end{array}$ & $\begin{array}{c}\text { RakaHota et } \\
\text { el }\end{array}$ & $\begin{array}{c}\text { Present } \\
\text { study }\end{array}$ \\
\hline Abdominal mass & $14.71 \%$ & $67.16 \%$ & $31.8 \%$ & $44 \%$ & $44 \%$ \\
\hline Abdominal Pain & $70.56 \%$ & $63.4 \%$ & $79.55 \%$ & $31 \%$ & $28 \%$ \\
\hline Menstrualirregularites & $4.41 \%$ & $14.4 \%$ & $9.1 \%$ & $17.4 \%$ & $24 \%$ \\
\hline Ascites & - & $4.7 \%$ & $18.1 \%$ & $1.3 \%$ & $04 \%$ \\
\hline Weight loss & - & $4.47 \%$ & - & $1.7 \%$ & $8 \%$ \\
\hline
\end{tabular}

Table 9: Distribution of ovarian neoplasm in different age group

\begin{tabular}{|l|c|c|c|c|c|}
\hline $\begin{array}{l}\text { Age group in } \\
\text { years }\end{array}$ & $\begin{array}{c}\text { Jagadeshwari } \\
\text { et al N=265(\%) }\end{array}$ & $\begin{array}{c}\text { Verma et al } \\
\mathbf{N = 4 0 3 ( \% )}\end{array}$ & $\begin{array}{c}\text { Ashraf et all } \\
\mathbf{N = 2 1 2 ( \% )}\end{array}$ & $\begin{array}{c}\text { RakaHota et all } \\
\mathbf{N = 2 3 0}(\boldsymbol{\%})\end{array}$ & Present study \\
\hline $0-10$ & - & $4(3.01 \%)$ & $1(.47 \%)$ & $3(1.3 \%)$ & - \\
\hline $11-20$ & $10(10.5 \%)$ & $13(9.77 \%)$ & $27(12.7 \%)$ & $17(7.4 \%)$ & $2(4 \%)$ \\
\hline $21-30$ & $25(26.3 \%)$ & $23(17.29 \%)$ & $64(30.19 \%)$ & $62(27 \%)$ & $8(16 \%)$ \\
\hline $31-40$ & $28(29.9 \%)$ & $63(27.7 \%)$ & $48(22.6 \%)$ & $78(34 \%)$ & $14(28 \%)$ \\
\hline $41-50$ & $20(21.05 \%)$ & $29(21.8 \%)$ & $39(18.4 \%)$ & $45(19.5 \%)$ & $16(32 \%)$ \\
\hline $51-60$ & $9(9.47 \%)$ & $22(16.54 \%)$ & $22(10.38 \%)$ & $9(4 \%)$ & $9(18 \%)$ \\
\hline $61-70$ & $3(3.16 \%)$ & $4(3.01 \%)$ & $8(3.77 \%)$ & $12(5.2 \%)$ & $1(2 \%)$ \\
\hline
\end{tabular}

Table 10: Frequency of histological types of ovarian neoplasm

\begin{tabular}{|l|c|c|c|c|c|c|}
\hline Histological Type & $\begin{array}{c}\text { Swammy and } \\
\text { Satyanarayan } \\
(\mathbf{n = 1 2 0})\end{array}$ & $\begin{array}{c}\text { Ashraf et } \\
\text { al(n=127) }\end{array}$ & $\begin{array}{c}\text { Jha and } \\
\text { Karki } \\
(\mathbf{n = 1 6 1})\end{array}$ & $\begin{array}{c}\text { Santosh et } \\
\mathbf{a l ( n = 9 5 7 )}\end{array}$ & $\begin{array}{c}\text { RakaHota } \\
\text { et el } \\
(\mathrm{n}=230)\end{array}$ & $\begin{array}{c}\text { Present } \\
\text { study } \\
(\mathbf{n = 5 0})\end{array}$ \\
\hline $\begin{array}{l}\text { Surface Epithelial } \\
\text { Tumours }\end{array}$ & $61.6 \%$ & $52.7 \%$ & $52.2 \%$ & $67.9 \%$ & $64.5 \%$ & $74 \%$ \\
\hline $\begin{array}{l}\text { Germ Cell } \\
\text { Tumours }\end{array}$ & $11.7 \%$ & $3.15 \%$ & $3.1 \%$ & $23.1 \%$ & $27 \%$ & $16 \%$ \\
\hline $\begin{array}{l}\text { Sex Cord Stromal } \\
\text { Tumours }\end{array}$ & $21.7 \%$ & $43.3 \%$ & $42.2 \%$ & $5.6 \%$ & $5.2 \%$ & $04 \%$ \\
\hline Others & $5 \%$ & $0.78 \%$ & $2.4 \%$ & $3.2 \%$ & $3.4 \%$ & $06 \%$ \\
\hline
\end{tabular}

\section{Conclusion}

Ovarian pathology is the widest and most complex problems in modern gynecology mainly through ovarian tumours. There is wide spectrum of clinical and pathological features of ovarian neoplasm. Proper clinical and histopathological correlation of and categorization according to WHO classification of ovarian neoplasm help in early diagnosis as well as prognosis of ovarian tumors. Histopathological examination remains the gold standard for diagnosing ovarian neoplasms.

\section{References}

1. Prof. Univ. Dr. Brăila Mihai, Kamal Kamal Constantin, Clinical-Epidemiological, Imagistic, Histological And Immunohistochemical Study Of Ovarian Mucinous Tumours University Of Medicine And Pharmacy Craiova. 
2. Adelmen $\mathrm{S}$, benson $\mathrm{CD}$, hertzler $\mathrm{JH}$, surgical lesion of the ovary in infancy \& childhood, surggy necolobstate 1975, 141 : 219-222

3. Gupta N, Bisht D, Agrawal AK, Sharma UK, Comoarative study of ovarian cyst and tumour, $\mathrm{J}$ Pak Medical association December 2000,50(12);416-419.

4. Scully RE, Clement PB, Young RH, Miscellaneous primary tumours, secondary tumours, and non-neoplastic lesions of ovary. In : Mills SE, Carter D, Greenson JK, Oberman HA, Renter V, Stoler MH edts. Sternberg's diagnostic surgical pathology, 4th edn. Philadelphia : Lippincott Williams and Wilkins; 2004.p. 2617

5. Zurawski VR, Jr, Orjaseter $H$, Andersen A, Jellum E. Elevated serum CA 125 levels prior to diagnosis of ovarian neoplasia: relevance for early detection of ovarian cancer. Int J Cancer. 1988;42:677680. [PubMed]

6. Lidor YJ, Xu FJ, Martinez-Maza O, Olt GJ, Marks JR, Berchuck A, et al.Constitutive production of macrophage colony-stimulating factor and interleukin-6 by human ovarian surface epithelial cells. Exp Cell Res.1993;207(2):332-9. doi:10.1006/excr.1993.1200.

7. Watson JM, Berek JS, Martinez-Maza O. Growth inhibition of ovarian cancer cells induced by antisense IL-6 oligonucleotides. Gynecol Oncol.1993; 49(1):8-15. doi:10.1006/gyno.1993.1077.

8. Lo CW, Chen MW, Hsiao M, Wang S, Chen CA, Hsiao SM, et al. IL-6 transsignaling in formation and progression of malignant ascites in ovarian cancer. Cancer Res. 2011;71(2):424-34. doi:10.1158/0008-5472.can-10-1496.

9. Friedman, EL, Hayes, DF, Kufe, DW. Reactivity of monoclonal antibody DF3 with a high molecular weight antigen expressed in human ovarian carcinomas. Cancer Res. 1986;46:5189-5194.

10. Bast, RC Jr, Knauf, S, Epenetos, A et al, Coordinate elevation of serum markers in ovarian cancer but not in benign disease. Hybridoma. 1987;6:228.

11. Gruhn JG. A selected historical survey pathology emphasizing neoplasms. In: Roth LM, Czernobilsky B (eds). Tumours and Tumour-like Conditions of the Ovary (Chapter 13). Churchill Livingstone: New York, 1985.

12. Graham H. Eternal Eve. The History of Gynaecology and Obstetrics. Doubleday and Company, Inc.: New York, 1951.

13. Pilli GS, Suneeta KP, Dhaded AV, Yenni VV. Ovarian tumours: a study of 282 cases. J Indian Med Assoc2002; 100: 420, 423-4, 447.Morgagni GB. The Seats and Causes of Diseases (English Translation by Benjamin Alexander). Miller A, Cadell T and Johnson and Payne: London, 1769.

14. Ahmad Z, Kayani N, Hasan SH, Muzaffar S, Gill MS. Histological pattern of ovarian neoplasm. J Pak Med Assoc2000; 50: 4169.

15. Oumachigui, Narasimhan KL, Reddy KS, et al. A clinicopathologic study of ovarian tumours in children. $J$ Obstet Gynecol. 1991;140:441-5.

16. Pilli GS, Suneeta KP, Dhaded AV, Yenni VV. Ovarian tumours: a study of 282 cases. J Indian Med Assoc2002; 100: 420, 423-4, 447.

17. Ahmad Z, Kayani N, Hasan SH, Muzaffar S, Gill MS. Histological pattern of ovarian neoplasm. J Pak Med Assoc2000; 50: 4169.

18. Rathi V et al Study Of Histopathological Spectrum Of Ovarian Lesions, Vikram University,Ujjain,2005.

19. Koonings PP, Campbell K, Mishell DR Jr, Grimes DA. Relative frequency of primary ovarian neoplasms: a10 year review. ObstetGynaecol1989; 74: 921-26 
20. Rafiq B, Kokab H, Rao SI. Ovarian tumours. Professional Med J 2005;12(4):397-403.

21. R Jha\& S Karki , Nepal Medical College,Journal 2008:109(2)81-85.

22. Levi1 F, Vecchia CL, Randimbison L, Te VC. Borderline ovarian tumours in Vaud. Switzerland: incidence, survival and second neoplasms. $\mathrm{Br} \quad \mathrm{J}$ Cancer 1999;79(1):4-6

23. Burkholz KJ, Wood BP, Zuppan C. Best Cases from the AFIP: Borderline papillary serous tumour of the right ovary. Radiographics 2005;25:1689-92.

24. Outwater EK, Siegelman ES, Kim B, Chiowanich P, Blasbalg R, Kilger A.

Ovarian Brenner tumours: MR imaging characteristics. MagnReson Imaging 1998;16:1147-53

25. Herbst AL. The Epidemiology of Ovarian Carcinoma and the Current Status of Tumour Markers to Detect Disease. Am JObstetGynecol 1994;170:1099-107.

26. Di Bonito L, Patriarca S, Delendi M, Alberico S. Ovarian tumours: anatomohistopathological contribution to their interpretation. Eur J GynaecolOncol1988; 9: 324-30.

27. Chakrabortti DK, Lee CMS. Epidemiological study ovarian neoplasms. J Obstetgynaecol India 1990; 40:582 -6.

28. Greggi S, Parazzini F, Paratore MP, Chatenoud L, Legge F, Mancuso S et al. Risk factors for ovarian cancer in central Italy. GynecolOncol 2000; 79:50-4.

29. Salazar-Martinez E, Lazeano-Pance EC, Gonzalez Lira-Lira G, Escudero- De Los Rios P, Salmeron-Castro J, HernandezAvila M. Cancer Res 1999; 59:3658-62.

30. Yen ML, Yen BL, Bai CH, Lin RS. Risk factors for ovarian cancer in Taiwan: a case control study in a low incidence population. GynecolOncol 2003; 89: 31824.
31. Zhang M, Lee AH, Binns CW. Reproductive and dietary risk factors for epithelial ovarian cancer in China. GynecolOncol 2004; 92: 320-6

32. KOLWIJICK, E. et al. Preoperative CA125 level in 123 patients with borderline ovarian tumors: a retrospective analysis and review of the literature. Int J Gynecol Cancer, v. 19, n. 8, p. 1335-8, 2009. [ Links ]

33. OSMAN, N. et al. Correlation of serum CA125 levels with stage, grade and survival of patients with epithelial ovarian cancer. J ClinOncol, v. 25, n.18, suppl. 16006, 2007. [ Links ] 